\title{
Test-taking strategies and students' achievement in EFL reading tests
}

\author{
Mehmet Tunaz $^{\text {a* }}$ (iD), Gülden Tüm ${ }^{\text {b }}$ iD \\ ${ }^{a}$ Erciyes University, School of Foreign Languages, Kayseri 38280, Turkey \\ ${ }^{b}$ Çukurova University, Adana, 01130, Turkey
}

\author{
APA Citation: \\ Tunaz, M., \& Tüm, G. (2019). Test-taking strategies and students' achievement in EFL reading tests. Journal of Language and Linguistic \\ Studies, 15(1), 140-150. \\ Submission Date: 04/05/2018 \\ Acceptance Date: 19/11/2018
}

\begin{abstract}
This research aims at investigating the effects of reading test-taking strategy training on EFL students' performance in English reading tests. The participants of the research were 90 prep-class students chosen randomly and divided into three groups of 30 students as face-to-face training group, online self-training group, and control group. The first group was involved in strategy training sessions for six weeks in school context (face-to-face) whereas the second group was only informed about the contend of the training sessions and directed to study through online strategy videos (online self-training). The last group was the control group the who were excluded from strategy training sessions. The reading test scores of the participants were analyzed via SPSS 16 with the aim of revealing whether or not there is an impact of strategy training. Moreover, semi-structured interviews were carried out with the participants, and the findings were analyzed through content analysis. Results of the research revealed that (a) the students' awareness of test taking strategies are in parallel with their test scores; (b) face-to-face strategy training was found to be more effective than online strategy training; (c) strategies related to 'drawing inference' and 'guessing the meaning from the context' were found to be the most effective ones while strategies such as detecting the question types, finding the main idea, skimming and scanning were other important strategies. The results suggested that strategy training on test taking might be included in the regular curriculums; students' awareness of test taking strategies should be fostered starting from the early stages of formal education; reading theories and strategies might be integrated into current reading courses with an inter-disciplinary model.
\end{abstract}

(C) 2019 JLLS and the Authors - Published by JLLS.

Keywords: Test taking strategies; EFL; reading test; strategy training

\section{Introduction}

Tests are still one of the most common assessment tools in almost all educational contexts due to their practical and time-saving features. As is the case, achievement in tests has been a crucial factor for learners to be assumed as academically successful. According to Hambleton et al. (1991), the test results of the learners can be affected by several factors such as cognitive, psychological, and test/learner related ones. In this vein, many studies have suggested that achievement in tests can be enhanced via teaching subject related test-taking strategies to the learners (e.g., Brown, 1999; Janowicz, 2007; Gray, 2011;

\footnotetext{
${ }^{*}$ Corresponding author. Tel.: +90-352-207-6666

E-mail address: mtunaz@erciyes.edu.tr
} 
Kesselman-Turkel \& Peterson, 2004). Teaching test-taking strategies, therefore, might be considered as a practical way of improving both learners' performance, and lessen anxiety.

As a very important part of language teaching, especially in EFL, language tests are in the core of strict criticism for their capacity as reliable and valid assessment tools, and as Allan (1992) stated, testtaking strategies and test-wiseness have been usually neglected in EFL and ESL testing literature. Therefore, the main purpose of this research is to inquire the potential impact of test-taking strategy training on EFL learners' performance in standard reading tests by comparing pre- and post-test scores of learners after a series of strategy training sessions.

\subsection{Literature review}

\subsubsection{Studies on general test-taking strategies}

In language teaching, despite the modern alternative testing methods, tests are still one of the best ways to assess a learners' ability (Hughes, 2003). Cohen (1984) stated that test-taking affects the construct validity since test constructor should take the test-taking process into account while setting a test. Hence, test-taking strategies are of the same importance due to their potential effects of fostering test achievement. Pike (1978) defines test-taking strategies as a combination of skills and knowledge of test-taking itself which leads learners to perform at their best advantage. Though suggested as a solution to all kinds of tests by some researchers (e.g., Pike, 1978; Scruggs \& Wastropieri, 1992; and Woodley, 1975), Bruch (1981) explains test taking strategies as an instruction, method or practice to understand and solve solely multiple choice questions. Test taking strategies, however, can vary depending on the different testing formats; that is, some strategies might be specific to a reading test while some others might be put into practice for a listening test. Namely, as Rupp et al. (2006) suggested, different testing types leads to different strategy use.

Several studies in literature investigated the effects of teaching test-taking strategies on learners' success. For instance, Janowicz (2007), states that test achievement is a valuable criterion to demonstrate a learnt ability, and in many fields of education learners are mostly evaluated according to their responses to standard tests. That's why, the content knowledge alone might not be sufficient to be successful in most cases. However, in the research conducted by Janowicz (2007) on young learners' test results, there was no remarkable difference between the students who received test taking instructions and those who were excluded.

In another research, Lance (2004) worked on the impact of teaching test-taking strategies to special education high school students. In the study, a number of disabled students were provided with some test-taking strategies and grid using methods. The main focus of this research was based on "No Child Left Behind Act" (2001). The results revealed the positive effects of teaching test taking strategies. Similarly, Scharnagl (2004) also found the positive effects of teaching test-taking strategies to learners to increase their academic achievement and suggested to integrate test-taking strategies into curriculum to improve test awareness. On the other hand, Bunting and Mooney (2001) conducted a study on, as they refer, test coaching and found out that test coaching might result in unreliable test scores. Edwards (2009) investigated the effects of test-taking strategies in terms of anxiety level of the learners, and found out that the students who received test-taking strategy training showed high level of anxiety in the last 30 minutes of an important exam, which suggests that strategy training might not always guarantee to lower anxiety in tests.

Considering the studies and their results in literature, this research is conducted to look into whether or not test-taking strategies have positive contribution to EFL learners' reading test results in standard exams. 


\subsubsection{Studies related to reading test-taking strategies}

Literature about reading test-taking strategies have mostly focused on teaching reading strategies, direct and integrated instruction of cognitive and metacognitive reading strategies, and the effects of different forms of strategy instructions on students' reading comprehension. In the study conducted by Du Plooy (1996), teaching reading strategies to students was found to contribute test scores particularly in two areas of comprehension; guessing the meaning from the context (vocabulary), and finding the main idea. The findings also indicated that reading strategy instruction would be effective if inserted into lessons by teachers. Another study by Singhal (1999) used a web-based reading strategy instruction program and found out that ESL learners became more aware of the strategies after the training and overall reading comprehension scores improved remarkably.

Çiçekoğlu (2003) conducted a study to inquire the effects of direct and integrated instruction of cognitive and metacognitive reading strategies. The results of the study contradicted with the previous similar studies in literature because the findings suggested that reading strategy instructions could not cause any statistically meaningful difference on students' performance after two weeks of strategy instruction. Supporting Çiçekoğlu (2003), Xia (2011) found out that total number of strategy use is unrelated to test performance since unsuccessful students were observed to use more metacognitive strategies than the successful ones. The results indicated that poor language proficiency, lack of automaticity and low reading rate would be the most obvious reading obstacles rather than the frequency of strategy use. Lee (2011), however, carried out a research on the strategy use and its effects on test performance, and suggested that test takers with high scores used strategies significantly more frequently than test takers with low scores. The participants who had high scores in this research used 'identification of important information by the discourse structure, vocabulary/sentence in context, and multiple-choice test-management' significantly more frequently by test takers with low scores.

\subsubsection{Research questions}

There have been countless studies in the literature of test taking and strategy training; however, investigating the effects of reading strategies in EFL and ESL context by comparing pre and post test results of the learners is not as common as general testing-related research. Therefore, the current study came out as a result of a wonder whether reading test-taking strategies would be taught directly to students through a strategy training program to enhance their test achievements, and whether these strategies would be integrated into current EFL/ESL curriculum or not. Thus, the following research questions were formed to guide the current research:

1. Is there a significant difference among students' pre-reading test performance in terms of their awareness of test taking strategies?

2. Is there a significant difference among the three groups of students' reading post- test performance: (a) strategy training group, (b) online self- training group, and (c) control group (notraining)?

3. What is the nature of students' perspective in dealing with a reading text as a result of the strategy training program?

\section{Method}

\subsection{Research design}

As the nature of the research questions requires, both qualitative and quantitative research models were applied in this research. Qualitative research method has a broad and open-ended focus at the beginning and it allows for important meanings to be discovered (Neuman, 2000); however, quantitative 
research methods seek to confirm hypotheses about phenomena, use highly structured methods such as questionnaire, surveys, quantifies variation, predict casual relationships, describe characteristics of a population, and their data format is numerical (Burns \& Grove, 2005). In the current research, experimental design covers the pre-test/post-test comparison. After randomly assigned to three groups, the participants solved the reading pre-test. Then, face-to-face training group had six weeks of reading strategy training while online self-training group was provided with the online strategy training sources and encouraged to search and learn about them on their own outside the classroom environment. The control group was excluded from strategy training sessions. At the end of the allotted training period, the groups were given reading post-test, and the results were analyzed through one-way ANOVA with SPSS 16.

\subsection{Participants}

The study was conducted with students from preparatory classes at the School of Foreign Languages at Erciyes University, Kayseri- Turkey. After the application of the Strategy Inventory for Language Learning (SILL) to randomly selected 250 students, 90 (46 females, 44 males) students who had close strategy-awareness levels were chosen as the participants of the study. The participants were randomly assigned to three different groups: (a) strategy training group, (b) online self- training group, and (c) control group (no-training).

\subsection{Data collection and instruments}

There were mainly three instruments in the data collection procedure. Strategy Inventory for Language Learners (SILL) version 7., reading comprehension test designed by the testing committee of the School of Foreign Languages, and semi-structured interview. SILL has 50 items structured as Likerttype scale. These items were designed to assess six strategy skills cited by Oxford (1990) as memory, cognitive, compensatory, metacognitive, affective, and social strategies. As stated by Demirel (2009), SILL has been translated into various languages and its reliability (Cronbach Alpha) has been between .93 and .98 .

The reading test used in pre- and post-test measure in data collection was developed by the testing committee at the School of Foreign Languages as a part of monthly exam. The reading test consisted of 30 questions related to six independent reading text, and its reliability was found quite high (KR-20 = .85 ) as indicated in Table 1. Each reading text had five question types which are main idea questions (MIQs), detail questions (DQs), vocabulary questions (VocQs), inference questions (InferQs)., and reference questions (ReferQs).

Table 1. Reliability Statistics of Reading Comprehension Test

\begin{tabular}{ccc}
\hline KR-20 & KR-20 & N of Items \\
& Based on Standardized Items & 30 \\
\hline $.852 *$ & .852 & \\
\hline
\end{tabular}

Note. $N=$ Number of Questions, $p^{*>}, 7$

The reading test was applied to the all groups both before and after the strategy training sessions which lasted six weeks. The participants in the face-to-face training group were taught reading and testtaking strategy instructions. The ones in the online self-training group, however, were provided with only limited instructions about the online sources regarding the weekly strategy training topics, and were 
encouraged to investigate with their own self-determination and autonomy. And, the third group, which was the control group of the research, were excluded from strategy training opportunities, and other instructors were also controlled in order to deny the control group's access to any reading or test-taking strategies related to current research.

After the strategy training sessions has been completed, the participants were involved into a semistructured interview to obtain details about how their perceptions of dealing with a reading test are affected by the strategy training sessions.

\subsection{Data analysis}

Data analysis for each research question are grouped and explained under the related headings below:

2.4.1. Research question 1: Is there a significant difference among students' pre-reading test performance in terms of their awareness of test taking strategies?

To answer first research question, the reading comprehension test was given to all the participants $(\mathrm{N}=90)$. The results were descriptively analyzed to search whether there is a significant difference among the three homogeneous groups in pre-test results, which required one-way ANOVA.

2.4.2. Research question 2: Is there a significant difference among the three groups of students' reading post-test performance: (a) strategy training group, (b) online self-training group, and (c) control group (no-training)?

As for the second research question, the participants' scores in the reading comprehension post-test were analyzed one-way ANOVA, and the results were compared with the pre-test results to find out the possible effects of strategy training sessions for each group.

\subsubsection{Research question 3: What is the nature of students' perspective in dealing with a reading text as a result} of the strategy training program?

The third question is the qualitative aspect of the research and dealing with the participants' perspectives about strategy training sessions and how these training period affected their attitudes towards reading text and tests. To answer this question, the participants of face-to-face and online selftraining groups responded semi-structured interview questions. The interview meetings were audiorecorded and transcribed for thorough content analysis.

\section{Results}

After the application of pre-test reading comprehension test, the results indicated that the mean scores were very close among the groups. Descriptive statistics of the post-test, however, revealed that the mean score of face-to-face training group increased more than the other groups as seen in Table 2.

Table 2. Mean scores in pre- and post-test

\begin{tabular}{lccc}
\hline Study Groups & N & Pre-test M & Post-test M \\
\hline Face to Face Training Group & 30 & 11.9333 & 20.1667 \\
Online Self-training Group & 30 & 12.0667 & 17.7333 \\
Control Group & 30 & 12.0333 & 15.5333 \\
Valid N (listwise) & 30 & & \\
\hline
\end{tabular}

Note. $N=$ number of test questions/participants, $M=$ Mean Scores 
Although the results obtained through descriptive statistics revealed that face-to-face strategy training led to positive effects on the students' test scores, a statistical analysis was needed to find out whether the difference among the groups was statistically meaningful. Thus, one-way ANOVA was conducted on SPSS 16 to compare the mean scores of groups for each question types.

The descriptive statistics of MIQs indicated that there was an increase in the mean scores of all groups but at different levels. One-way ANOVA results proved that There was a statistically significant effect of the independent variable, which was strategy training in this case, on test scores in main idea questions at the $\mathrm{p}<.05$ level for the three conditions $[\mathrm{F}(2,87)=13.95, \mathrm{p}=0.001]$. This result was in parallel with Du Plooy (1996) who claimed that students find main idea questions easy because of the traditional reading comprehension activities which usually focus on finding main idea.

As for the detail questions (DQs), there was an increase in the mean scores of all groups compared pre-test results. One-way ANOVA results indicated that there was a statistically important difference between groups resulting from strategy training in detail questions the $\mathrm{p}<.05$ level for the three conditions $[\mathrm{F}(2,87)=27.30, \mathrm{p}=0.001]$. The findings were compatible with Yousefand \& Lotfi $(2001)$, which found that positive effects of strategy training process in detail questions. The improvement in the detail questions might result from the scanning technique presented during the training programs.

For vocabulary questions (VocQs), the results obtained from one-way ANOVA revealed that the difference between the means scores was not statistically meaningful at the $\mathrm{p}<.05$ level for the three conditions $[\mathrm{F}(2,87)=1.97, \mathrm{p}=0.146]$. This results suggested that the increase in the mean scores in VocQs are not resulted from strategy training manipulation. Çiçekoğlu (2003) also found that reading strategy instructions failed to foster students' performance in vocabulary questions. However, Du Plooy (1996) reached a contradictory result by claiming that strategy training would improve students' competence in guessing meaning of a word from the context.

The increase in the amount of mean scores for inference questions were also found to be different for each group, and one-way ANOVA results both face-to-face group and online self-training group caused meaningful difference from control group. When all the groups were considered, there was a significant contribution of strategy training in terms of inference questions at the $p<.05$ level for the three conditions $[\mathrm{F}(2,87)=12.62, \mathrm{p}=0.001]$. Though there are relatively few studies in the literature, Brown et al. (1996), and Spörer et al. (2009) mentioned the positive implications of strategy training for inference performance, which is in parallel with the findings of this research.

As the last question type, the difference between the pre- and post-test performance for reference questions were also analyzed with one-way ANOVA, and strategy training was found to be a leading factor to increase the students' scores in reference questions at the $\mathrm{p}<.05$ level for the three conditions $[\mathrm{F}(2,87)=15.91, \mathrm{p}=0.001]$.

The qualitative data answering the third research question was obtained through a semi-structured interview which focused on eight questions related to the students' perception of strategy training sessions. The main purpose of the interview was to find out the chance in students' confidence and autonomy when dealing with a reading test. Although most of the students mentioned the positive contribution of strategy training, their responses were grouped under two categories as 'the strategies reported as useful and practical' and 'the strategies reported as difficult to apply'.

Content analysis of the transcribed interview meetings revealed that the most commonly stated strategies as useful and practical were 'finding the main idea' (16/30) and 'detecting the question type' (13/30), which were followed by skimming (8/30), scanning (8/30), and switching reference word to crosscheck (6/30). The strategies found most difficult to apply according to the students were stated as 'guessing the vocabulary in the context' (14/30), and 'drawing inference from the text' $(10 / 30)$. These reports would explain the low increase in the post-test vocabulary question, and supported the findings 
of one-way ANOVA related to vocabulary questions. However, it is still important that the students in face-to-face training group were aware of their negative and positive aspects, and this would be explained as the effect of strategy training on students' autonomy and self-awareness.

\section{Discussion and Conclusion}

The participants in this study were chosen according to their responses to SILL, and the pre-test results indicated that the students in all groups had similar scores from pre-test reading exam. This finding was quite parallel with Lee (2011) who claimed that test-taker with high scores use strategies more frequently than test-takes with low scores because the participants in our study groups were all at similar level in SILL (Oxford, 1989) and had similar results from pre-test reading exam. This means that participants' strategy awareness levels are similar as well.

Regarding the second research question, although students in all groups had similar results from pretest reading exam, the students in face-to-face training group performed better than the other two groups in the post-test reading exam. The difference between the post-test scores of face-to-face and selftraining group were not statistically meaningful, which indicated that strategy training is effective both as a classroom instruction and as assignment for online practices. The control group also increased the mean score slightly in post-test. This might result from ongoing formal education process. In this vein, the results of this research contradicted with that of Edwards (2009) which found out that strategy training might also cause high anxiety for learners and strategy training might not always guarantee to lower anxiety in test taking process. The findings also contradicted with the results of study conducted by Janowicz (2007) which revealed that there is no specific difference between the achievement of young leaners who received strategy training and who were deprived of these strategies.

Strategy training process failed to create any difference between the control group and experimental groups in vocabulary questions. The increase in the mean scores for all groups in post-test was statistically not caused by the strategy training process because the difference between the groups was not found statistically meaningful in one-way ANOVA. These results were in accordance with the findings of Çiçekoğlu (2003), which revealed that reading strategy instruction failed to bring about any significant difference on students' performance after two weeks of strategy instruction. According to DU Plooy (1996), however, strategy training would increase students' competence especially when guessing meaning of a word from the context. For this reason, vocabulary might still be a crucial part of reading strategy training although it was found to be ineffective in this study.

The interview sessions revealed that strategy training program improved the students' confidence while dealing with a reading test. Students' statements about specific strategies indicated that the posttest results were in parallel with the students' views, because students' most commonly uttered that they still had difficulty in vocabulary related strategies after the training sessions, and their scores of vocabulary related questions in post-test exam were supporting their opinions.

\section{Implications}

Strategy training can also be conducted via directing learners to search and learn on their own. In this vein, self-learning and peer interaction should be encouraged among students in EFL classrooms. In order to foster self-learning, technology can also be very effective and should be integrated to engage language learners in the learning process. A well-organized internet based environment could also be very useful to follow students who are instructed to do research on their own. Such a facility could also 
enable students to share their search results with each other, which is commonly suggested in educational context as peer learning.

To sum up, in this study, strategy training was found to enhance students' performance in reading tests. For this reason, depending on the findings of the study, it can be suggested that strategy training should be a main component of the regular curriculum for reading classes in foreign language teaching. Namely, reading theories and strategies should be integrated with the regular reading courses with an inter-disciplinary model.

\section{Acknowledgements}

This research is based on the corresponding author's the Master of Arts thesis conducted at Çukurova University, Adana in 2014.

\section{References}

Allan, A. (1992). 'Development and validation of a scale to measure test-wiseness in EFL/ESL reading test takers'. Language Testing,9(2),101- 122.

Brown, R., Pressley, M., Van Meter, P., \& Schuder, T. (1996). A quasi-experimental validation of transactional strategies instruction with low-achieving second-grade readers. Journal of educational psychology, 88(1), 18.

Bruch, M. A. (1981). Relationship of test-taking strategies to test anxiety and performance: Toward a task analysis of examination behaviour. Cognitive Therapy and Research, 5(1), 41-56.

Bunting, B.P. \& Mooney, E. (2001). The effects of practice and coaching on test results for educational selection at 11 years of age. Educational Psychology.21(3), 243-253.

Burns, N., \& Grove, S. K. (2005). Selecting a quantitative research design. In N. Burns, \& S. K. Grove (Eds), The Practice of Nursing Research: Conduct, Critique, and Utilization, 5th edition (231272). St Louis, MO: Elsevier Saunders.

Cohen, A. (1984). On Taking tests: what the students report. Language Testing, I, 70-81.

Çiçekoğlu, D. (2003). The effects of direct and integrated instruction of cognitive and metacognitive reading strategies at awareness-raising level on reading proficiency and strategy use (Unpublished Doctoral dissertation). Middle East Technical University. Turkey.

Demirel, M. (2009). The validity and reliability study of Turkish version of strategy inventory for language learners. World Applied Sciences Journal, 7(6), 708-713.

Du Plooy, A. (1996). Reading Strategies for Effective Reading Comprehension (Unpublished Doctoral dissertation). Potchefstroom University for Christian Higher Education, Potchefstroom, NorthWest.

Edwards, J. (2009). Physical activity and test anxiety. School Science and Mathematics, 109, 5-7.

Hableton, R., Swaminathan., \& Rogers, H. (1991). Fundamentals of item response theory. Sage Publications, Inc.

Hughes, A. (2003). Testing for Language Teachers. Syndicate of the University of Cambridge. Common test techniques: 5- 75 .

Janowicz, T. (2007). Teaching Test Taking Strategies to Improve Self-Efficacy and Academic Achievement (Chapman University College). Retrieved from Erciyes University Database. 
Kesselman-Turkel, J., Peterson, F. (2004). Test Taking Strategies. Madison, WI, USA: University of Wisconsin Press. P: 14.

Lance, L. (2004). The Effects of Teaching Test-Taking Strategies to High School Special Education Students on Achievement Scores on The New Jersey High School Proficiency Assessment. Dissertations \& theses, Widener University, Retrieved from ProQuest

Lee, J. Y. (2011). Second language reading topic familiarity and test score: test-taking strategies for multiple-choice comprehension questions. (Doctoral dissertation). The University of Iowa.

Neuman, W.L. (2000). Social Research Methods- Qualitative and quantitative approaches. Allyn and Bacon Pub pub.

Oxford, R. L. (1990). Language learning strategies: What every teacher should know. New York: Newbury House/Harper \& Row.

Pike, L. (1978). Short term instruction, test-wiseness, and the Scholastic Aptitude Test: A literature review with research recommendations. Princeton, NJ: ETS.

Rupp, A. A., Ferne, T., \&Choi, H. (2006). How assessing reading comprehension with multiple-choice questions shapes the construct: A cognitive processing perspective. Language Testing, 23(4), 441474.

Scharnagl, T. (2004). The Effects of Test Taking Strategies on Students' Reading Achievement. Dissertations \& theses, Union Institute and University Cincinnati, Ohio, Retrieved from ProQuest

Scruggs, T. E., \& Mastropieri, M. A. (1992). Teaching test-taking skills: Helping students show what they know. Purdue University: Brookline Books.

Singhal, M. (1999). The effects of reading strategy instruction on the reading comprehension, reading process and strategy use of adult ESL readers. Retrieved in March 15, 2014 from: https://arizona.openrepository.com/arizona/handle/10150/248211

Spörer, N., Brunstein, J. C., \& Kieschke, U. L. F. (2009). Improving students' reading comprehension skills: Effects of strategy instruction and reciprocal teaching. Learning and Instruction, 19(3), 272286.

Woodley, K. K. (1975). Test-wiseness: A cognitive function? Paper presented at National Council on Measurement in Education, Washington, DC.

Xia, Y. (2011). Efficient reading in standardized tests for EFL learners: a case study of reading strategies used by Chinese English major students in TEM-4. Retrieved in March 20, 2014 from: http://www.diva-portal.org/smash/record.jsf?pid=diva2:429440

Yousefvand, Z., \& Lotfi, A. R. (2011). The Effect of Strategy-Based Reading Instruction on Iranian EFL Graduate Students Reading Comprehension and Their Attitudes Toward Reading Strategies Instruction. Journal of Academic and Applied Studies, 1(5), 39-55. 


\section{Test çözme stratejileri ve öğrencilerin yabancı dil olarak İngilizce okuma sınavı başarıları}

\section{$\ddot{O} \mathbf{z}$}

$\mathrm{Bu}$ araştırma, üniversite hazırlık sınıfı öğrencilerine verilen okuma testi yanıtlama stratejileri eğitiminin öğrencilerin İngilizce okuma testlerindeki başarılarına etkisini incelemek amacıyla yapılmıştır. Araştırma Kayseri Erciyes Üniversitesinin farklı bölümlerini kazanmış, yabancı dil olarak İngilizce eğitimi alan 90 hazırlık sınıfı öğrencisi ile gerçekleştirilmiştir. Çalışmanın başlangıcında, başlangıç seviyesindeki 250 öğrenciye, okuma testi yanıtlama stratejileri farkındalığını ölçmek ve ne sıklıkla bu stratejileri kullandıklarını tespit etmek amacıyla anket uygulanmıştır. Anket sonuçlarına göre ortalamanın altında kalan öğrencilerden rastgele seçilen 90 öğrenci eşit üç ayrı gruba ayrılmıştır. Birinci gruba altı hafta boyunca okuma testi yanıtlama stratejileri üzerine eğitim verilirken ikinci grup sadece konu başlıklarından haberdar edilerek internet üzerinden bireysel çalışmaları sağlanmıştır. Rastgele seçilen 30 kişilik son grup ise hiçbir eğitim ya da yönlendirme almamıştır. Öğrencilere verilen strateji eğitiminin, okuma test puanlarına etkilerini araştırmak amacıyla öğrencilerin test sonuçları karşılaştırılmıştır. Ayrıca öğrencilerle yüz yüze yarı yapılandırılmış görüşmeler yapılmış ve bu görüşmeler içerik çözümlemesi yöntemiyle incelenmiştir. Bulgular üç temel sonucu ortaya çıkarmıştır. Öğrencilerin test çözme strateji farkındalıkları ile test başarıları paralellik göstermektedir (a). Yüz yüze strateji eğitimi alan öğrencilerin okuma testi başarılarının bireysel çalışmalara yönlendirilen öğrencilerin ve hiçbir eğitime dâhil edilmeyen kontrol grubu öğrencilerinin okuma testi başarılarından yüksek olduğu saptanmıştır (b). Okuma testi strateji eğitiminden sonra yapılan görüşmelerde, öğrencilerin okuma testlerinde en çok zorladıkları stratejilerin, kelime anlamlarının bağlamdan tahmin edilmesi ve çıkarım yapma sorularında olduğu saptanmıştır (c). Öğrencilerin en kolay bulduğu ve en rahat uygulayabildiğini ifade ettiği stratejiler ise; soru türünün tespit edilmesi, ana fikrin bulunması, detaylı ve yüzeysel okuma olarak tespit edilmiştir. Bu çalışmadan elde edilen bulgular ışığında, okuma testi strateji eğitiminin mevcut eğitim programlarına dâhil edilmesi ve öğrencilerin test çözme stratejileri farkındalıklarının artırılması ve okuma teorileriler ve stratejilerinin güncel müfredata dâhil edilmesinin faydaları vurgulanmıştır.

Anahtar sözcükler: Test yanıtlama stratejileri; yabancı dil eğitimi; okuma testi; strateji eğitimi

\section{AUTHOR BIODATA}

Mehmet Tunaz is an English language teaching instructor in Erciyes University, School of Foreign Languages. Currently he is a PhD candidate at Erciyes University, English Language and Literature Department. He got the MA degree from Çukurova University, English Language Teaching Department in 2014; BA degree also from Çukurova University, English Language Teaching Department in 2010. Program evaluation and development for language teaching, language teaching methodologies, teacher education and development, curriculum design and assessment/evaluation in language teaching are among the fields of his interest.

Gülden TÜM is currently an associate professor of at the English Teaching Language Department at Çukurova University, where she has taught since 1986. Ms. TÜM has been teaching at both undergraduate and graduate levels at the Department of Foreign Language Education. Between 1988 and 1992 she taught Turkish and Turkish Culture voluntarily in the Family Support Center and at Maryland University, at the American Base, Adana, Turkey. Since then, she has taught Turkish as a foreign language. Between 2004 and 2006, she was appointed as Turkish Language Instructor by the Ministry of Education and the Ministry of Foreign Affairs to work as a Turkish Language Instructor in Belarus in two universities: Minsk State Linguistics University and Belarus State Economic University. Nowadays, she writes articles and language books: Turkish exercise book, test book, and reading book in order to help foreign learners of Turkish learn Turkish. In 2012, she went to several American Universities such as Portland State University, Princeton University, NY University, Columbia University, U-Penn, Yale University 
to teach and observe Turkish lessons, to use her Turkish reading draft book and to exchange knowledge with several Turkish Language Instructors (Erika H. Gilson, Pelin Başçı, Feride Hatipoğlu, Güliz Kuruoğlu, Ahmet Okal, Ethem Erol, Zübeyde Colak, Sibel Erol). 